Tohoku J. exp. Med., 1964, 82, 373-386

\title{
Changes of the Nucleic Acid Content in the Rabbit Organs under the Irradiation of Roentogen Ray
}

\author{
By \\ Norichika Miyawaki \\ From the Department of Obsterics and Gynecology, Tohoku University \\ School of Medicine, Sendai; Director: Prof. K. Kushima
}

(Received for publication, March 9, 1964)

\begin{abstract}
The present study was made of the effect of the X-ray irradiation and the intravenous injections of the radiopathogenic substance (Radiotoxin A) on the content and the base composition of the nucleic acid in the liver, spleen, adrenal glands and bone marrow of rabbits.

The conclusions are as follows: (1) In rabitts with symptoms of radiation disturbance RNA in the liver and adrenal glands and DNA in the spleen and bone marrow showed a marked decrease. (2) Similar findings were obtained in the groups of injection of the radiopathogenic substance, Radiotoxin A. Especially in the group of serial injections of Radiotoxin A changes of RNA or DNA in the organs were more remarkable than in the groups irradiated with X-ray. (3) The base composition of the nucleic acid was changed by the $\mathrm{X}$-ray irradiation or the intravenous injection of Radiotoxin A. That is, adenine of RNA in the liver decreased markedly and adenine of DNA in the spleen and bone marrow decreased too. Cytosine and uracil of RNA in the liver and cytosine and thymine of DNA in the spleen decreased, whereas cytosine of DNA in the bone marrow increased. Especially in the group of serial injections of Radiotoxin A there were the most remarkable ehanges.
\end{abstract}

Friedrich Miescher laid the foundation of the research of nucleic acid and Altman succeeded in the extraction of nucleic acid. Since Casperson and Bracht's study it has been believed that nucleic acid plays an important role in mechanism of cells. Desoxyribonucleic acid (DNA) composes chromatin and gene in a nucleus, and ribonucleic acid (RNA) takes a part in protein synthesis. A considerable amount of research has been reported on the influence of X-ray on nucleic acid since Michell's paper ${ }^{1}$. By the physio-chemical analysis of the nucleic acid fraction extracted from organs and tissues, depolymerization of nucleic acids was evidenced as a decrease of their viscosity and double refraction of flow. The nucleic acid synthesis in tissues was suppressed by X-ray in trace works using $\mathrm{P}^{32}$ and $\mathrm{C}^{14}$. Controversy continued as to histological or microspectrophotometrical observations on the effect of X-ray on the nucleic acid content in

宮脇法倧 
tissues. So far, little work has been done to study the extraction of nucleic acids for quantitative determination and especially the base composition of the acids.

Kushima and Yoshizaki ${ }^{2}$ reported that comparing with serum or plasma blood cells had a strong effect in inducing radiation disturbances in rabbits which had been irradiated serially with $\mathrm{X}$-ray. The substance supposed to give the effect of causing radiation disturbances to blood cells was called Radiotoxin A by Kushima.

An attempt was made in this work to determine biochemically the nucleic acid content and its base composition in the liver and the adrenal glands, which have a low radiosensitivity, and in the spleen and bone marrow, which have a high radiosensitivity after X-ray irradiation or Radiotoxin A injection in rabbits.

\section{MATERIALS AND METHODS}

\section{Materials}

Experimental animal: Mature female rabbits weighing approximately $3 \mathrm{~kg}$ were used.

$\mathrm{X}$-ray appratus: The X-ray source used was a deep therapy machine operated at $20 \mathrm{~mA}$ and $180 \mathrm{KVp}$ with filters of $0.7 \mathrm{~mm} \mathrm{Cu}+0.5 \mathrm{~mm} \mathrm{Al}$ (Model KXC-18 manufactured by Tokyo Shibaura $\mathrm{Co}$ ). Under this condition the dose rate was approximately $63.5 \mathrm{r} / \mathrm{min}$.

Radiotoxin A: This radiopathogenic substance was extracted by Kushima and Yoshizaki's method from blood cells in rabbits which showed symptoms of radiation disturbance such as leucopenia after X-ray irradiation to the hypogastrium of normal rabbits. A dosage of 500r was irradiated once a day for eight days successively (total $4000 \mathrm{r}$ ). Thirty-three $\mathrm{mg}$ of Radiotoxin A were yielded from blood cells of a normal rabbit and $90 \mathrm{mg}$ from those of a X-ray irradiated rabbit.

2. Methods

Animals were given intravenously a single injection of $15 \mathrm{mg}$ of Radiotoxin A per $\mathrm{kg}$ of body weight and successive injections of $10 \mathrm{mg}$ per $\mathrm{kg}$ for five days.

The extraction and quantitative analysis of nucleic acid: The rabbits were killed by decapitation. The quickly excised liver, spleen, adrenal glands and bone marrow were chilled in cracked ice and weighed. After homogenizing these organs, RNA and DNA were extracted by Schneider's method ${ }^{3,4)}$. They were subjected to color reaction by Mejabum's method ${ }^{5)}$ (orcin-HCl reaction) and Dische's method ${ }^{6}$ ) (diphenylamine reaction) respectively, determined with a Beckmann spectrophotometer and recorded in the equivalent phosphorous content.

The base composition of the nucleic acid: The samples of RNA and DNA for studing the base composition were extracted by Kay and Dounce's and Kay, and Simmons, Dounce's method ${ }^{7,8)}$ with sodium dodecyl sulfate from the rabbit 
organs. The analysis of the nucleic acid compositions was performed by a paperchromatography applying Smith and Markham's method9). The nucleic acid was hydrolysed with $\mathrm{N}-\mathrm{HCl}$ at $100^{\circ} \mathrm{C}$ for $1 \mathrm{hr}$. To make a solvent, take $700 \mathrm{ml}$ of pure tert-butanol (at $26^{\circ} \mathrm{C}$ ) and $132 \mathrm{ml}$ of constant boiling $\mathrm{HCl}$ and make up to $1000 \mathrm{ml}$ with water at $20^{\circ} \mathrm{C}$. Chromatographic analysis was accomplished with one dimensional ascending method $\left.{ }^{10}\right)$ using Toyo Roshi filter paper No. 51 A. The spots on the developed chromatograms were located in short wave ultraviolet light (Manaslu-light 1536A). The spots on the chromatogram were cut, together with the corresponding blanks, and each was extracted for at least $18 \mathrm{hr}$. in $5 \mathrm{ml}$ of $0.1 \mathrm{~N} \mathrm{HCl}$ in a test tube (pyrimidine; $0.01 \mathrm{~N} \mathrm{HCl}$ ). The density of the solution was then read in a Beckmann spectrophotometer, the following data being used ${ }^{11)}$.

$$
\begin{array}{ll}
\text { Adenine } \mathrm{D}_{250}=12.8 & \text { Guanine } \mathrm{D}_{\mathbf{2 6 0}}=11.4 \\
\text { Cytosine } \mathrm{D}_{275}=10.44 & \text { Uracil } \mathrm{D}_{\mathbf{2 6 0}}=8.29 \\
\text { Thymine } \mathrm{D}_{\mathbf{2 6 5}}=7.95 &
\end{array}
$$

The density $\mathrm{D}$ is for a cell $1 \mathrm{~cm}$ thick, the subscript referring to wavelength. The concentration is $10^{-3} \mathrm{M}$. The solvent separates guanine, adenine, cytidylic acid and uridylic acid.

\section{RESULTS}

Nucleic acid contents of rabbit organs after $X$-ray irradiation and intravenous injection of Radiotoxin $A$

1. Organ weight and total amount of nucleic acid in organs (mg RNA-p and DNA-p per organ, wet weight)

Liver: As compared to the weight of the liver in the control, the decrease rate for one in the groups of X-ray irradiation was as follow: in the group of hypogastrium irradiation of $\mathrm{X}$-ray, the rate was $7.77 \%$; epigastrium irradiation of X-ray, $5.43 \%$; a single injection of Radiotoxin A, $4.1 \%$; and serial injections of Radiotoxin A, 8.1\%. Both values of RNA-1p and DNA-p decreased, but the decrease rate for RNA-p was higher than that for DNA-p. Especially by a series of injections of Radiotoxin A, RNA-p was decreased by $49.4 \%$, namely about one half of RNA-p in the normal liver.

Spleen: The decrease rate of the spleen weight was much higher than that of the liver weight, that is, in the group of hypogastrium irradiation of X-ray, the rate was $10.0 \%$; epigastrium irradiation of X-ray, $7.31 \%$; a single injection of Radiotoxin A, 5.6\%; and a series of injections of Radiotoxin A, 10.5\%. In the nucleic acid content, both values of RNA-p and DNA-p decreased. DNA-p in the group of serial injections of Radiotoxin A decreased remarkably by $51.1 \%$.

Adrenal glands: As to the decrease rate of the adrenal glands weight, in the group of hypogastrium irradiation of X-ray, $5.46 \%$; epigastrium irradiation of $\mathrm{X}$-ray, $4.88 \%$; a single injection of Radiotoxin A, 3.7\%; and a series of injections 
of Radiotoxin A, 7.6\%. RNA-p in the adrenal glands decreased extremely, especially in the group of serial injections of Radiotoxin A by as high as $57.7 \%$, as compared to $41.2 \%$ in the group of hypogastrium irradiation of X-ray and $39.1 \%$ in that of epigastrium irradiation of X-ray. DNA-p decreased by $24.9 \%$ in the group of serial injections of Radiotoxin A, whereas by 5.5\% in the group of hypogastrium irradiation of $X$-ray and 5.0 in that of epigastrium irradiation of $X$-ray, respectively.

Bone marrow: The decrease rate of the bone marrow weight was $4.85 \%$

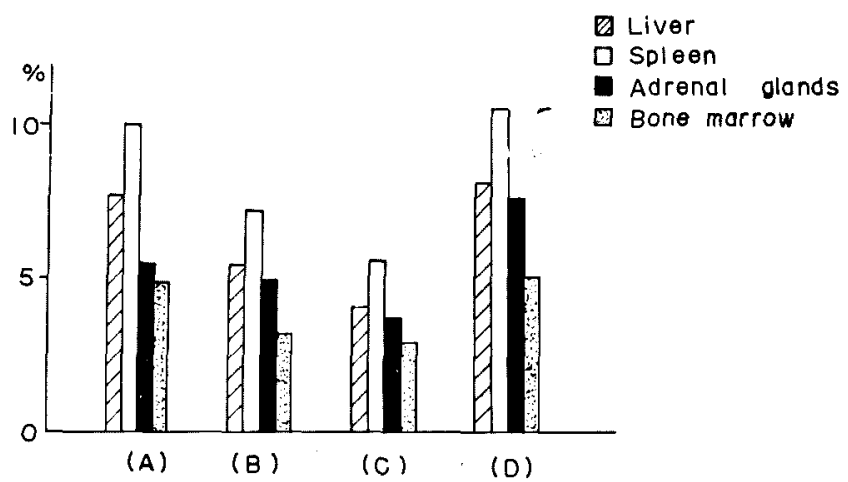

Fig. 1. Decrease rate of organ weight in the liver, spleen, adrenal glands and bone marrow after X-ray irradiation and Radiotoxin A injection in rabbits.

Key: (A): hypogastrium irradiation of $X$-ray.

(B): epigastrium irradiation of X-ray.

(C): a single injection of Radiotoxin A.

(D): a series of injections of Radiotoxin A.

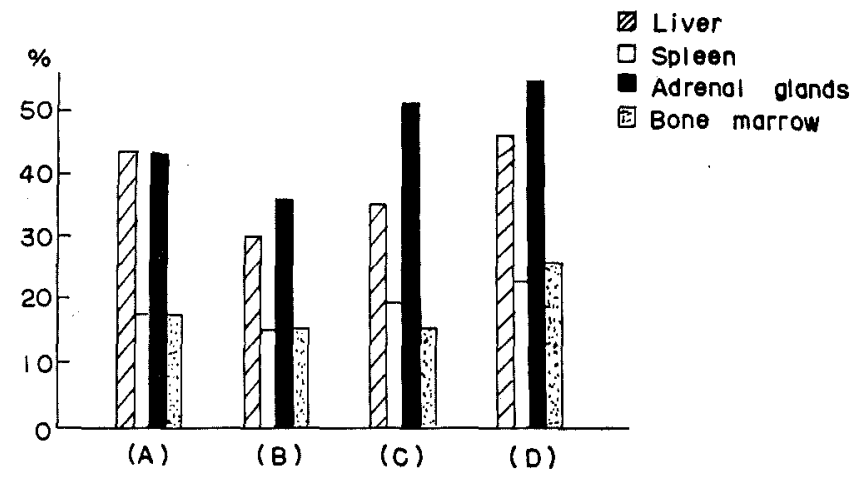

Fig. 2. Decrease rate of the RNA in the liver, spleen, adrenal glands and bone marrow after X-ray irradiation and Radiotoxin A injection in rabbits. 


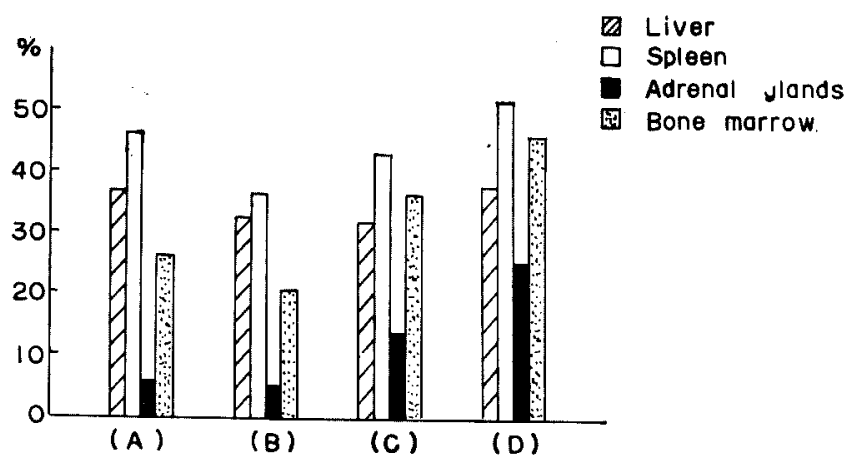

Fig. 3. Decrease rate of the DNA in the liver, spleen, adrenal glands and bone marrow after $\mathrm{X}$-ray irradiation and Radiotoxin $\mathrm{A}$ injection in rabbits.

in the group of hypogastrium irradiation of X-ray; $3.12 \%$ in the epigastrium irradiation of $\mathrm{X}$-ray; $2.9 \%$ in a single injection of Radiotoxin $\mathrm{A}$; and $5.0 \%$ in a series of injections of Radiotoxin A. As to the nucleic acid content, the decrease rate of DNA-p was higher than one of RNA-p. That is, DNA in the epigastrium irradiation of X-ray decreased by $20.5 \%$; in a single injection of Radiotoxin $A$, by $3.61 \%$; and in serial injections of Radiotoxin A, by $48.1 \%$, whereas RNA in the hypogastrium irradiation of X-ray, by $21.2 \%$ and in serial injections of Radiotoxin A, by $29.6 \%$.

2. Nucleic acid content in tissues (mg RNA-p and DNA-p per $100 \mathrm{mg}$ tissues, wet weight)

Liver: The decrease rate of RNA-p was higher than that of DNA-p in the liver. That is, in the group of hypogastrium irradiation of $\mathrm{X}$-ray the rate was $43.2 \%$; epigastrium irradiation of X-ray, $29.3 \%$; a single injection of Radiotoxin A, $34.7 \%$, a series of injections of Radiotoxin A, $45.5 \%$, as to DNA-p, hypogastrium irradiation of X-ray, $36.8 \%$; and a series of injections of Radiotoxin A, $37.3 \%$.

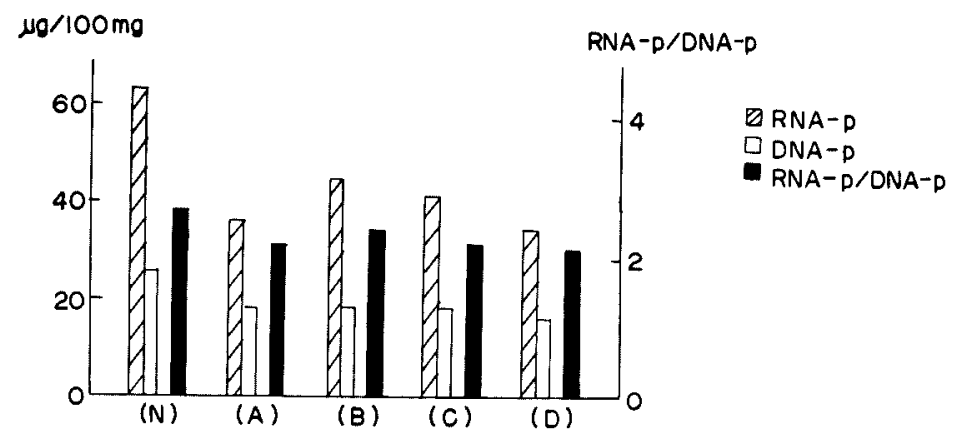

Fig. 4. Changes of the nucleic acid content in the liver after $X$-ray irradiation and Radiotoxin $\mathbf{A}$ injection in rabbits.

(N): normal 
Spleen: On the contrary, in the spleen DNA-p decreased much more than RNA-p. That is, in the group of hypogastrium irradiation of X-ray the decrease rate of DNA-p was $40.3 \%$; epigastrium irradiation of X-ray, $31.0 \%$; a single injection of Radiotoxin A, 39.4\%; and a series of injections of Radiotoxin A, $45.3 \%$. The decrease rate of RNA-p was $17.6 \%$ in hypogastrium irradiation of $\mathrm{X}$-ray and $22.2 \%$ in a series of injections of Radiotoxin $\mathrm{A}$.

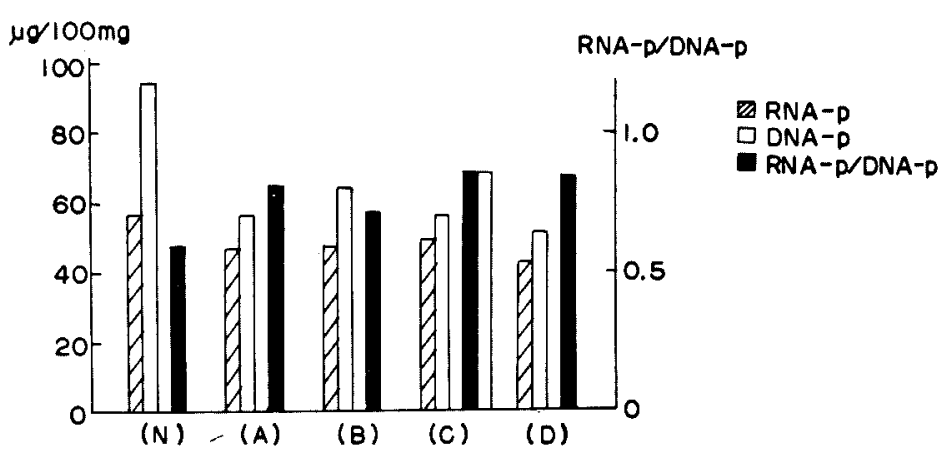

Fig. 5. Changes of the nucleic acid content in the spleen after $X$-ray irradiation and Radiotoxin A injection in rabbits.

Adrenal glands: In these organs the decrease rate of RNA-p was higher than that of DNA-p, the decrease rate of RNA-p in adrenal glands in the group of hypogastrium irradiation of X-ray was $42.8 \%$; epigastrium irradiation of X-ray, $35.8 \%$; a single injection of Radiotoxin A, $50.9 \%$; and a series of injections of Radiotoxin A, $54.0 \%$, while the decrease rate of DNA-p in the group of hypogastrium irradiation of X-ray was $5.3 \%$ and in a series of injections of Radiotoxin A was $18.2 \%$.

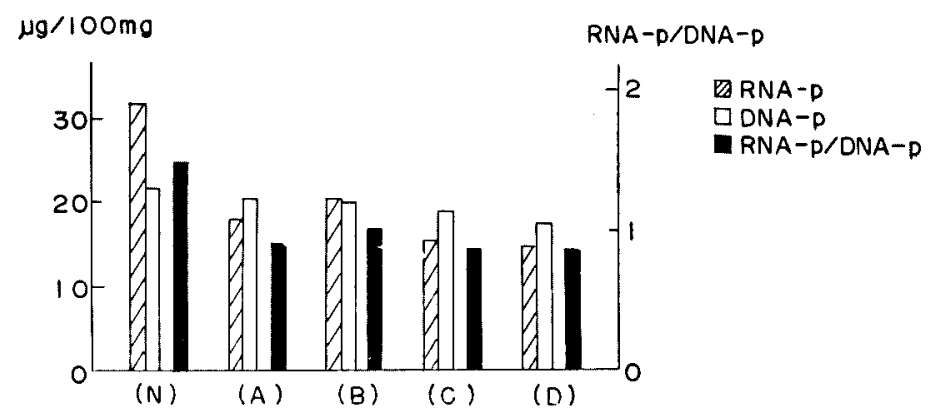

Fig. 6. Changes of the nucleic acid content in the adrenal glands after $\mathrm{X}$-ray irradiation and Radiotoxin A injection in rabbits. 
Bone marrow: Comparing the decrease rate of DNA-p with that of RNA-p in the bone marrow, the former was higher than the latter. For example, DNA-p decrease rate in the hypogastrium irradiation of $\mathrm{X}$-ray was $22.9 \%$; epigastrium irradiation of X-ray, $21.4 \%$; a single injection of Radiotoxin $\mathrm{A}, 34.7 \%$; and in serial injections of Radiotoxin A was $45.3 \%$, but RNA-p decrease rate in the hypogastrium irradiation of X-ray was $17.1 \%$ and in serial injections of Radiotoxin A was $25.7 \%$.

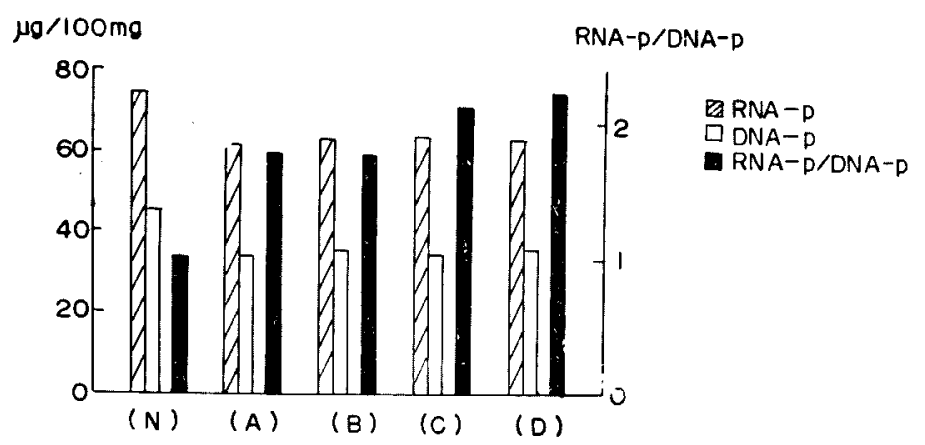

Fig. 7. Changes of the nucleic acid content in the bone marrow after X-ray irradiation and Radiotoxin $\mathrm{A}$ injection in rabbits.

3. Change of RNA-p/DNA-p ratio in tissues

RNA-/DNA-p ratio means the ratio RNA-p content to DNA-p content in a cell.

Liver: In this organ RNA-p decreased more than DNA-p. Therefore the RNA-p/DNA-p ratio was smaller. As compared to 2.70 in the normal the ratio in the group of hypogastrium irradiation of $\mathrm{X}$-ray was 2.18 ; epigastrium irradiation of X-ray, 2.40; a single injection of Radiotoxin A, 2.22; and a series of injections of Radiotoxin A, 2.12 .

Spleen: On the contrary, the decrease rate of DNA-p was more remarkable than that of RNA-p in the spleen. So the RNA-p/DNA-p ratio was larger. The ratio in the group of hypogastrium irradiation of $\mathrm{X}$-ray was 0.82 ; epigastrium irradiation of X-ray, 0.73 ; a single injection of Radiotoxin $\mathrm{A}, 0.85$; and a series of injections of Radiotoxin A, 0.84 , while 0.59 in the normal level.

Adrenal glands: The RNA-p/DNA-p ratio was smaller because of the remarkable decrease of RNA-p content in these organs. That is, 1.49 in the normal; 0.90 in the group of hypogastrium irradiation of X-ray; 1.01 in the epigastrium irradiation of X-ray; 0.82 in a single injection of Radiotoxin $A$; and 0.84 in serial injections of Radiotoxin A.

Bone marrow: The decrease rate of DNA-p being higher than that of RNA-p, the RNA-p/DNA-p ratio was larger: 1.06 in the normal: 1.79 in the hypoga- 
strium irradiation of X-ray; 1.78 in the epigastrium irradiation of X-ray; 2.12 in a single injection of Radiotoxin $\mathrm{A}$; and 2.12 in serial injections of Radiotoxin A.

The base composition of the nucleic acid after $X$-ray irradiation and injections of Radiotoxin $A$

1. The base composition of the nucleic acid by weight

Liver: Adenine, of compositions of RNA in the liver, decreased below the control in both groups of the X-ray irradiations and injections of Radiotoxin $\mathbf{A}$. The value of adenine in the group of the hypogastrium irradiation of $\mathrm{X}$-ray was 0.50 ; epigastrium irradiation of X-ray, 0.49 ; a single injection of Radiotoxin A, 0.41 ; and a series of injections of Radiotoxin A, 0.38, as compared to 0.52 in the normal. Guanine showed no significant difference between these experimental gropus and the control groups. Cytosine and uracil in the group of a series of injections of Radiotoxin A decreased markedly to 0.54 and 0.48 respectively, as compared to 0.63 and 0.51 in the control. Therefore the value of

TABLe I. Purine and Pyrimidine Composition of the RNA in the Liver, Spleen and Bone Marrow after X-ray Irradiation and Radiotoxin A Injection in Rabbits

\begin{tabular}{|c|c|c|c|c|c|c|c|c|}
\hline \multicolumn{2}{|r|}{ Sample } & \multicolumn{7}{|c|}{$\mu \mathrm{mol} / \mathrm{mg}$} \\
\hline Organ & Treatment & A & G & C & $\mathrm{U}$ & $\mathrm{Pu} / \mathrm{Py}$ & $\mathrm{G}+\mathrm{C} / \mathrm{A}+\mathrm{U} \mid$ & Total bases \\
\hline \multirow{6}{*}{ Liver } & Normal & 0.52 & 0.88 & 0.63 & 0.51 & 2.23 & 1.46 & 2.54 \\
\hline & $\begin{array}{l}\text { X-ray irradiation } \\
\text { Hypogastrium }\end{array}$ & 0.50 & 0.88 & 0.62 & 0.48 & 1.24 & 1.54 & 2.47 \\
\hline & Epigastrium & 0.49 & 0.88 & 0.61 & 0.49 & 1.24 & 1.52 & 2.49 \\
\hline & Radiotoxin A & & & & & & & \\
\hline & A single inj: & 0.41 & 0.81 & 0.61 & 0.50 & 1.10 & 1.57 & 2.32 \\
\hline & & & & 0.04 & 0.48 & 1.11 & & \\
\hline \multirow{6}{*}{ Spleen } & Normal & 0.53 & 0.55 & 0.54 & 0.44 & 1.10 & 1.12 & 2.05 \\
\hline & X-ray irradiation & 059 & 0.54 & 0.53 & 0.44 & 10 & 1,12 & 2.04 \\
\hline & Epigastrium & 0.52 & 0.54 & 0.53 & 0.43 & 1.10 & 1.13 & 2.03 \\
\hline & Radiotoxin A & & & & & & & \\
\hline & A single inj. & 0.52 & 0.54 & 0.53 & 0.43 & 1.11 & 1.18 & 2.01 \\
\hline & A series of inj. & 0.51 & 0.54 & 0.53 & 0.43 & 1.10 & 1.32 & 1.95 \\
\hline \multirow{6}{*}{$\begin{array}{l}\text { Bone } \\
\text { marrow }\end{array}$} & Normal & 0.45 & 0.58 & 0.56 & 0.37 & 1.10 & 1.39 & 1.95 \\
\hline & $\begin{array}{l}\text { X-ray irradiation } \\
\text { Hypogastrium }\end{array}$ & 0.44 & 0.58 & 0.56 & 0.37 & 1.09 & 1.41 & 1.95 \\
\hline & Epigastrium & 0.44 & 0.57 & 0.56 & 0.37 & 1.09 & 1.40 & 1.95 \\
\hline & Radiotoxin A & & & & & & & \\
\hline & A single inj. & 0.44 & 0.57 & 0.56 & 0.37 & 1.09 & 1.40 & 1.94 \\
\hline & A series of inj. & 0.44 & 0.57 & 0.56 & 0.37 & 1.09 & 1.40 & 1.93 \\
\hline
\end{tabular}

A: adenine G: guanine C: cytosine U: uracil Pu: purine Py: pyrimidine 
$\mathrm{Pu} / \mathrm{Py}$ was changed to 1.24 in the group of hypogastrium irradiation of $\mathrm{X}$-ray; 1.24 in the epigastrium irradiation of $\mathrm{X}$-ray; 1.10 in a single injection of Radiotoxin A; and 1.17 in a series of injections of Radiotoxin A, whereas the normal was 1.23. The value of $\mathrm{G}+\mathrm{C} / \mathrm{A}+\mathrm{U}$ was changed too. The total bases showed a significant decrease. That is, 2.47 in the group of hypogastrium irradiation of X-ray; 2.49 in the epigastrium irradiation of X-ray; 2.32 in a single injection of Radiotoxin A; and 2.19 in serial injections of Radiotoxin A, while 2.54 in the normal. There were produced no changes in the composition of DNA in the liver by X-ray irradiation and a single injection of Radiotoxin, A, but there were slight decreases in adenine and thymine in the group of serial injections of Radiotoxin A.

Spleen: In the group of X-ray irradiation and a single injection of Radiotoxin A, RNA in the spleen showed no changes in its composition. Adenine, cytosine and uracil decreased slightly whereas guanine did not show any change in the group of serial injections of Radiotoxin A. Adenine in compositions of DNA in the spleen decreased in the group of X-ray irradiation and a single injection of Radiotoxin A: as compared to 0.75 in the normal evel, it was 0.73 in hy-

TABle II. Purine and Pyrimidine Composition of the DNA in the Liver, Spleen and Bone Marrow after X-ray Irradiation and Radiotoxin A Injection in Rabbits

\begin{tabular}{|c|c|c|c|c|c|c|c|c|}
\hline \multicolumn{2}{|r|}{ Sample } & \multicolumn{7}{|c|}{$\mu \mathrm{mol} / \mathrm{mg}$} \\
\hline Organ & Treatment & A & G & $\mathrm{C}$ & $\mathrm{T}$ & $\mathrm{Pu} / \mathrm{Py}$ & $\mathrm{G}+\mathrm{C} / \mathrm{A}+\mathrm{T}^{*}$ & Total bases \\
\hline \multirow{5}{*}{ Liver } & Normal & 0.72 & 0.67 & 0.42 & 0.68 & 1.26 & 0.77 & 2.49 \\
\hline & $\begin{array}{l}\text { X-ray irradiation } \\
\text { Hypogastrium }\end{array}$ & 0.72 & 0.66 & 0.42 & 0.68 & 1.26 & 0.78 & 2. 48 \\
\hline & Epigastrium & 0.72 & 0.68 & 0.42 & 0.68 & 1.26 & 0.77 & 2.48 \\
\hline & Radiotoxin A & 71 & 067 & 041 & 0.68 & 1,27 & 0.79 & 2.47 \\
\hline & A series of inj. & 0.70 & 0.67 & 0.41 & 0.67 & 1.27 & 0.79 & 2.45 \\
\hline \multirow{5}{*}{ Spleen } & Normal & 0.75 & 0.72 & 0.52 & 0.73 & 1.17 & 0.84 & 2.71 \\
\hline & $\begin{array}{l}\mathbf{X} \text {-ray irradiation } \\
\text { Hypogastrium }\end{array}$ & 0.73 & 0.72 & 0.52 & 0.73 & 1.17 & 0.84 & 2.68 \\
\hline & Epigastrium & 0.73 & 0.72 & 0.51 & 0.71 & 1.20 & 0.86 & 2.67 \\
\hline & $\begin{array}{l}\text { Radiotoxin A } \\
\text { A single inj. }\end{array}$ & 0.74 & 0.71 & 0.50 & 0.65 & 1.26 & 0.87 & 2.60 \\
\hline & A series of inj. & 0.72 & 0.71 & 0.47 & 0.63 & 1.30 & 0.87 & 2.54 \\
\hline \multirow{5}{*}{$\begin{array}{l}\text { Bone } \\
\text { marrow }\end{array}$} & Normal & 0.71 & 0.55 & 0.51 & 0.63 & 1.10 & 0.79 & 2.40 \\
\hline & $\begin{array}{l}\text { X-ray irradiation } \\
\text { Hypogastrium }\end{array}$ & 0.70 & 0.55 & 0.52 & 0.62 & 1.10 & 0.81 & 2.40 \\
\hline & Epigastrium & 0.71 & 0.55 & 0.51 & 0.63 & 1.10 & 0.80 & 2.40 \\
\hline & $\begin{array}{l}\text { Radiotoxin A } \\
\text { A single inj. }\end{array}$ & 0.70 & 0.55 & 0.53 & 0.63 & 1.08 & 0.81 & 2.40 \\
\hline & A series of inj. & 0.69 & 0.54 & 0.53 & 0.63 & 1.04 & 0.83 & 2.37 \\
\hline
\end{tabular}

*T: thymine 
pogastrium irradiation of X-ray; 0.73 in epigastrium irradiation of X-ray; 0.74 in a single injection of Radiotoxin $A$; and 0.72 in serial injections of Radiotoxin $A$. Guanine showed no significant difference between these groups. Cytosine and thymine in the group of injection of Radiotoxin A decreased much more than those in the group of X-ray irradiation, especially in the group of serial injections of Radiotoxin A these two compositions decreased markedly from 0.52 and 0.73 to 0.47 and 0.63 respectively. The value $\mathrm{Pu} / \mathrm{Py}$ was changed to $1.17 \mathrm{in}$ hypogastrium irradiation of $\mathrm{X}$-ray; 1.20 in epigastrium irradiation; 1.26 in a single injection of Radiotoxin A; and 1.30 in serial injections of Radiotoxin A, as compared to 1.17 in the normal. $\mathrm{G}+\mathrm{C} / \mathrm{A}+\mathrm{U}$ value was varied. The total bases showed a decrease: 2.68 in hypogastrium irradiation of X-ray; 2.68 in epigastrium irradiation of X-ray; 2.60 in a single injection of Radiotoxin $A$; and 2.54 in serial injections of Radiotoxin $A$, as compared to 2.71 in the normal.

Bone marrow: There was no significant change in the composition of RNA in the bone marrow in both groups of $\mathrm{X}$-ray irradiation and a single injection of Radiotoxin A. In serial injections of Radiotoxin A, adenine and uracil decreased slightly while guanine and cytosine did not show any changes. As for the

TABle III. Purine and Pyrimidine Composition of the RNA (\% Molar Proportion) after X-ray Irradiation and Radiotoxin A Injection

\begin{tabular}{|c|c|c|c|c|c|}
\hline \multicolumn{2}{|c|}{ Sample } & \multicolumn{4}{|c|}{$\%$ Molar proportion } \\
\hline Organ & Treatment & A & $\mathrm{G}$ & $\mathrm{C}$ & $\mathbf{U}$ \\
\hline \multirow{6}{*}{ Liver } & Normal & 20.62 & 34.60 & 24.77 & 20.00 \\
\hline & $\mathrm{X}$-ray irradiation & 1083 & 3550 & 2501 & 1955 \\
\hline & Epigastrium & 19.89 & 35.53 & 24.72 & 20.04 \\
\hline & Radiotoxin A & & & & \\
\hline & A single inj. & 17.54 & 34.93 & 26.13 & 21.39 \\
\hline & A series of inj. & 17.41 & 36.63 & 24.51 & 21.68 \\
\hline \multirow{6}{*}{ Spleen } & Normal & 25.67 & 26.75 & 26.15 & 21.42 \\
\hline & X-ray irradiation & 0579 & (96 75 & 91 & 01 \\
\hline & Epigastrium & 25.68 & 26.76 & 26.28 & 21.23 \\
\hline & Radiotoxin A & & & & \\
\hline & A single inj. & 25.68 & 26.82 & 26.17 & 21.33 \\
\hline & A series of inj. & 25.67 & 26.82 & 26.27 & 21.23 \\
\hline \multirow{6}{*}{$\begin{array}{l}\text { Bone } \\
\text { marrow }\end{array}$} & Normal & 22.77 & 29.46 & 28.59 & 19.13 \\
\hline & X-ray irradiation & & & & \\
\hline & Hypogastrium & 22.40 & 29.57 & 28.59 & 19.34 \\
\hline & Badiotoxin A & & & & \\
\hline & A single inj. & 22.78 & 29.48 & 28.71 & 19.02 \\
\hline & A series of inj. & 22.53 & 29.59 & 29.02 & 18.87 \\
\hline
\end{tabular}


composition of DNA in the bone marrow; in all groups adenine decreased and cytosine increased, whereas guanine and thymine were not different from the control.

2. The base composition of the nucleic acid

The base composition of the nucleic acid by weight is expressed in molar per cent of constituents. Adenine in compositions of RNA in the liver decreased in both groups of X-ray irradiation and a series of injections of Radiotoxin $A$. In these groups guanine and uracil increased slightly. Among compositions of DNA in the liver, guanine increased in the groups of Radiotoxin A, and adenine cytosine and uracil did not show any changes. In the spleen, there was not significant difference in compositions of RNA in all groups from the control. Adenine and guanine of DNA increased, while cytosine and thymine decreased in all groups. As to RNA compositions of the bone marrow, in groups of X-ray irradiation and a single injection of Radiotoxin A they were not changed significantly, but in the group of serial injections of Radiotoxin A cytosine increased and uracil decreased. In compositions of DNA of the bone marrow, adenine decreased, cytosine and thymine increased and guanine had no change in all groups.

TABLE IV. Purine and Pyrimidine Composition of the DNA ( $\%$ Molar Proportion) after X-ray Irradiation and Radiotoxin A Injection

\begin{tabular}{|c|c|c|c|c|c|}
\hline \multicolumn{2}{|c|}{ Sample } & \multicolumn{4}{|c|}{$\%$ Molar proportion } \\
\hline Organ & Treatment & A & $\mathrm{G}$ & $\mathrm{C}$ & $\mathbf{T}$ \\
\hline Liver & $\begin{array}{l}\text { Normal } \\
\text { X-ray irradiation } \\
\text { Hypogastrium } \\
\text { Epigastrium } \\
\text { Radiotoxin A } \\
\text { A single inj. } \\
\text { A series of inj. }\end{array}$ & $\begin{array}{l}28.89 \\
\\
28.91 \\
29.08 \\
\\
28.78 \\
28.49\end{array}$ & $\begin{array}{l}26.89 \\
\\
26.77 \\
26.58 \\
\\
27.08 \\
28.04\end{array}$ & $\begin{array}{l}16.70 \\
16.98 \\
16.89 \\
\\
16.69 \\
18.53\end{array}$ & $\begin{array}{l}27.53 \\
\\
27.34 \\
27.41 \\
\\
27.45 \\
24.93\end{array}$ \\
\hline Spleen & $\begin{array}{l}\text { Normal } \\
\text { X-ray irradiation } \\
\text { Hypogastrium } \\
\text { Epigastrium } \\
\text { Radiotoxin A } \\
\text { A single inj. } \\
\text { A series of inj. }\end{array}$ & $\begin{array}{l}24.49 \\
\\
29.36 \\
29.66 \\
\\
29.19 \\
28.58\end{array}$ & $\begin{array}{l}22.80 \\
\\
22.78 \\
22.79 \\
\\
22.74 \\
27.29\end{array}$ & $\begin{array}{l}21.33 \\
\\
21.85 \\
21.41 \\
\\
22.01 \\
16.71\end{array}$ & $\begin{array}{l}26.18 \\
26.01 \\
26.15 \\
\\
26.06 \\
27.40\end{array}$ \\
\hline $\begin{array}{l}\text { Bone } \\
\text { marrow }\end{array}$ & $\begin{array}{l}\text { Normal } \\
\text { X-ray irradiation } \\
\text { Hypogastrium } \\
\text { Epigastrium } \\
\text { Radiotoxin A } \\
\text { A single inj. } \\
\text { A series of inj. }\end{array}$ & $\begin{array}{l}27.19 \\
27.49 \\
\\
28.29 \\
28.19\end{array}$ & $\begin{array}{l}26.75 \\
27.07 \\
\\
27.39 \\
22.90\end{array}$ & $\begin{array}{l}18.97 \\
18.99 \\
\\
19.19 \\
22.45\end{array}$ & $\begin{array}{r}27.68 \\
26.50 \\
\\
25.16 \\
26.45\end{array}$ \\
\hline
\end{tabular}




\section{DISCUSSION}

Controversy continued as to the influence of the $\mathrm{X}$-ray irradiation on the nucleic acid content of tissues. There have been many reports on this subject, for example those of Grégoire ${ }^{12)}$, Kohler ${ }^{13)}$, Paigen \& Kaufmann ${ }^{14}$, Ely \& Ross ${ }^{15)}$, Berenbom ${ }^{16)}$, Petrakisis) and others, but their results are considerably different according to the dosis of $\mathrm{X}$-ray or the assay method for quantitative determination of nucleic acids. Though Kohler and Petrakis demonstrated histo-chemically the nucleic acid content of tissues for quantitative determination, a question is raised as to whether the nucleic acid content will be able to be estimated by histo-chemical staining methods. Shibatani ${ }^{18)}$ suggested in his histo-chemical study that changes in dyeing or distribution of nucleic acids in a cellular would rather be due to changes in volume or type of other components in a cellular. Rose ${ }^{19)}$ also hypothesized that the degree to which the nucleic acid is stained increases with the connection of nucleic acid and protein.

As to the effect of X-ray on the liver, Kolodny ${ }^{20}$ ) and Mills ${ }^{21)}$ reported the liver got necrosis by the X-ray irradiation, and Petrakis presented the findings of disappearance of DNA and changes of RNA by the X-ray irradiation. Nagai contradicted Paigen's result that both DNA and RNA in the liver decreased by irradiating the whole body of a mouse with $600 \mathrm{r}$ of X-ray. From the radiological biochemical concept, changes of DNA and RNA in tissues occurred within such short time as forty-eight hours after the $\mathrm{X}$-ray irradiation should be judged carefully ${ }^{14}$.

In this present paper, both RNA-p and DNA-p in the liver decreased in the groups of the X-ray irradiation and the intravenous injection of Radiotoxin $A$. Especially RNA-p showed a marked decrease. Weight of the liver decreased drastically too, especially in the group of serial injections of Radiotoxin A. Inferences are drawn from these data that weight as well as RNA-p component in the liver decreases markedly as the effect of X-ray.

It is generally accepted that in a radio-sensitive organ such as spleen, tissues or cells are damaged severely by the X-ray irradiation.

Since Nicholas Senn and Heinecke's report ${ }^{23-25}$ ) there are many papers on the effect of X-ray on the spleen. Waymouth ${ }^{26)}$ reported that DNA in the spleen decreased to a level which is about a half of the normal in three hours after $\mathrm{X}$-ray irradiation and RNA had a decrease of the same order of magnitude in three or four days.

In our experiments, DNA-p and RNA-p in this organ decreased significantly in all experimental groups, marking a remarkable loss of weight of the spleen. These findings are marked especially in the group of serial injections of Radiotoxin A. It is reasonable to presume that a decrease in weight of the spleen is caused by a loss of blood by contraction of the organ in the early period and direct 
effects of Radiotoxin A in the later period.

Selye presented his theory of "General adaptation syndrome" in 1938. He stressed the great importance of the pituitary adrenal system in the syndrome. Langendorff \& Lorenz ${ }^{27)}$ and Mauer ${ }^{28)}$ have studied histologically or chemically on the effect of X-ray irradiation on adrenal glands. But these are still many unanswered questions concerning this organ. Büchell, Dougherty \& White ${ }^{29}$ ) and Asakawa ${ }^{30}$ proved that leucopenia caused by $\mathrm{X}$-ray irradiation depends on lymphopenia mainly and the adrenal cortex plays an important role in his lymphopenia. The work of Asakawa indicated that on the first day of X-ray irradiation the function of the pituitary- adrenal system is accelerated and afterwards gradually supressed. Ishibashi ${ }^{31)}$ described that the X-ray irradiation is one of strong stress, but if the irradiation is too strong, it induces changes in the adrenal glands and the hypophysis not by stress, but by another effect of the X-ray.

In our experiment, RNA-p in the adrenal glands decreased markedly, whereas DNA-p decreased slightly in the $\mathrm{X}$-ray irradiation and the intravenous injection of Radiotoxin A. In the group of serial injections of Radiotoxin A, RNA-p and DNA-p showed the most remarkable decrease.

Studies on changes in the bone marrow by the X-ray irradiation have been carried out by Heinecke, Aubertin ${ }^{32)}$, Ssipowsky ${ }^{33)}$, Bloom ${ }^{34)}$ and Fliedner ${ }^{35}$. According to Heinecke's histo-chemical study, there is no marked change in the bone marrow by the X-ray irradiation, but Ssipowksy has noted the severe hyperemia or edema in the organ. Kelly ${ }^{36}$ and Mandel $^{22}$ reported that the bone marrow as well as the spleen has a high radiosensitivity and a decrease of DNA in the bone marrow is induced by the X-ray irradiation.

Our results agree with this theory. It is supposed that decreases of nucleic acid contents in the bone marrow after the $\mathrm{X}$-ray irradiation will be caused by suppressing the process of nucleic acid synthesis and also by selectively damaging high radiosensitive tissues in the organ. Our findings are highly suggestive of the direct effect of Radiotoxin $A$ on the bone marrow to induce a decrease of nucleic acids.

Little work has been done to study the changes of the base composition of the nucleic acid by the $\mathrm{X}$-ray irradiation.

In our experiment the following results were obtained: Among compositions of RNA in the liver, adenine decreased markedly while cytosine and uracil decreased slightly, marking a decrease in the total bases and a change of the values of $\mathrm{Pu} / \mathrm{Py}$ and $\mathrm{G}+\mathrm{C} / \mathrm{A}+\mathrm{U}$ in all experimental groups. As to compositions of DNA in the spleen, adenine, cytosine and thymine showed a decrease. Adenine of DNA composition in the bone marrow decreased only in the group of serial injections of Radiotoxin A. These findings were first observed by us. It can be understood from the above that the nucleic acid precursor is effective for symptoms such as leucopenia and radiation sickness caused by the radiotherapy. Therefore it 
is of considerable practical significance that as a therapy of side-effects of the radiotherapy not only the use of adenine derivatives, but also that of cytosine and pyrimidine derivatives may be considered.

\section{References}

1) Mitchell, J.S., Brit. J. exp. Path., 1942, 23, 285.

2) Kushima, K. \& Yoshizaki, H., Tohoku J. exp. Med., 1961, 74, 286.

3) Schnedier, W.C., J. biol. Chem., 1945, 161, 293.

4) Schneider, W.C., ibid., 1946, 164, 747.

5) Dische, Z., The Nucleic Acids., Academic Press, N.Y., 1955, p. 287.

6) Mejbaum, W., Z. physiol. Chem., 1939, 258, 117.

7) Kay, E.R., Simmons, N.S. \& Dounce, A.L., J. Amer. chem. Soc., 1952, 74, 1724.

8) Kay, E.R., \& Dounce, A.L., ibid., 1953, 75, 4041.

9) Smith, J.D. \& Markham, R., Biochem. J., 1950, 46, 509.

10) Masamune, H. \& Sakamoto, M., Tohoku J. exp. Med., 1955, 61, 353.

11) Masamune, H. \& Sakamoto, M., ibid., 1955, 61, 4.

12) Grégoire, F.E. \& Grégoire, C., Arch. inter. Med. expth., 1934, 9, 283.

13) Kohler, P.C., Nature, 1934, 233.

14) Paigen, K. \& Kaufamann, B.N., J. cell. comp. Physiol., 1953, 42, 163.

15) Ely, J.O. \& Ross, M.H., Cancer Res., 1948, 8, 285.

16) Berenbom, M., Radiation Res., 1956, 5, 650.

17) Petrakis, N.L., Naval Def. Lab. Rep. A.D., 1949, 126.

18) Shibatani, T., Protein, Nucleic Acid and Enzyme (Jap.), 1958, 2, 271.

19) Rose, R., A.M.A. Arch. of Path., 1954, 58, 345.

20) Kolodny, A., Amer. J. Path., 1925, 1, 285.

21) Mills, G.P., Lancet, 1910, 2, 462.

22) Mandel, T., Radiobiol., 1956.

23) Heinecke, H., Munch. med. Wschr., 1904, 51, 785.

24) Heinecke, H., Med. u. Chir., 1905, 14, 21.

25) Heinecke, H., Munch. med.W Wshr., 1913, 60, 2657.

26) Weymouth, P.P. \& Kaplan, H.S., Cancer Res., 1952, 12, 680.

27) Langendorff, H. \& Lorenz, W., Strahlentherapie., 1952, 88.

28) Mauer, H.J., ibid., 1955, 96.

29) Dougherty, T.F. \& White, A., Endocrinol., 1947, 41, 230.

30) Asakawa, K., Nipp. Act. Radiol. (Jap.), 1957, 17, 1331.

31) Ishibashi, M., Hiroshima J. med. Sci. (Jap.), 1959, 8, 291.

32) Aubertin, Ch., Arch. Méd. exp., 1904, 20, 273.

33) Ssipowsky, P.W., Beitr. path. Anat., 1934, 94, 1.

34) Bloom, W., Histopathology of Irradiation from External and Internal Source, Mo. GrawHill Book Company, Inc. N.Y., 1948, 62.

35) Fliedner, T., Strahlentherapie., 1956, 101, 289.

36) Kelly, L.F., Biophysics, 1957, 8. 